\title{
Ethnomedical uses of plants from Salyan District, Nepal
}

\author{
Puran P. Kurmi ${ }^{1}$ and Sushim R. Baral ${ }^{2}$
}

\begin{abstract}
In an attempt to record the local peoples' knowledge on traditional use of plants for medicine, this study was conducted at various places of Salyan district. The local residents, especially traditional healers who have accumulated knowledge on medical use of plants from their forefathers are the principal source of information of this paper. Since time immemorial, the people of Salyan district have used plants for curing various health ailments. However, with the growing awareness on immediate benefit of modern medicines, the knowledge on use of plants has been reported decreasing at a fast pace, and the time is not very far when the rest of the knowledge is suspected to deplete completely. In the present study, 77 species belonging to 60 families have been identified on use in the district for curing various health ailments. According to key informants, the number of species is far too low than before.
\end{abstract}

Keywords: Ethnomedicine, traditional knowledge, ailments, Salyan District, Nepal

H istorically plants used in traditional medicine by the indigenous populations across the world have produced some of the most useful modern day pharmaceuticals (Medora 2001 in Joshi and Joshi 2001). Of the 75,000 plants used in different systems of medicine, more than 20,000 species of higher plants are used in the traditional treatment practices of indigenous cultures living around the world (Ved Prakash 1998). Over 15,000 species are identified in Asia as drug yielding plants, of which about 8000 in India and 7000 in China are being used in different system of health care (Chaudhary et al 2004). It is estimated that various communities in Nepal use approximately 1000 species of wild plants in traditional medicinal practice (Chaudhary 1998), a substantial number still await documentation.

Review of literatures indicate that the botanical exploration of $1803 \mathrm{AD}$ by Buchanan-a French medical professional could be called as the first ethnobotanical work in Nepal, however the first paper on this subject in Nepal was published by Pandey (1955), followed by more works from the mid 70s to till date. Rajbhandari (2001) has compiled majorities of such publications followed by an excellent book on Nepal's ethnobotany by Manandhar (2002).

Many traditional systems of medicine are now being gradually documented in Nepal. This is particularly true for folk and ethnomedicines using plant species, which pass from one generation to other simply by words. Documentation of indigenous knowledge on uses of plants among the people is being welcomed these days. It not only helps conserve such plants but also for using them as future prospects of therapeutic development. The World Health Organisation has estimated that about 80 percent of the populations in developing countries depend on traditional medicine for their primary health care needs. Many such plants also have other domestic uses. It is therefore very important that studies in ethnobotany and ethnopharmacology continue so as to preserve traditional knowledge.

The present study is one such attempt. It documents traditional knowledge on use of plants for curing various ailments by the local residents of Salyan District. The information accumulated here will be of use to the readers, and related researchers in future.

\section{Methods}

The present research was conducted at various places throughout Salyan District (see map). Plants occurring at an altitude ranging from 1000 to $2000 \mathrm{~m}$ have been included in this research. The survey and recording of enthnomedicinal uses of plants was carried out for about two months in fields. Immediately after the collection of plants, their morphalogical features were noted right on fields. Key informants such as local elderly people and traditional healers were identified and consulted for recording of medicinal uses of these plants in the locality. The collected species were brought to the National Herbarium and Plant Laboratories,

1 Department of Plant Resources, Thapathali, Kathmandu

2 Department of Forest Research and Survey, Babarmahal, Kathmandu 


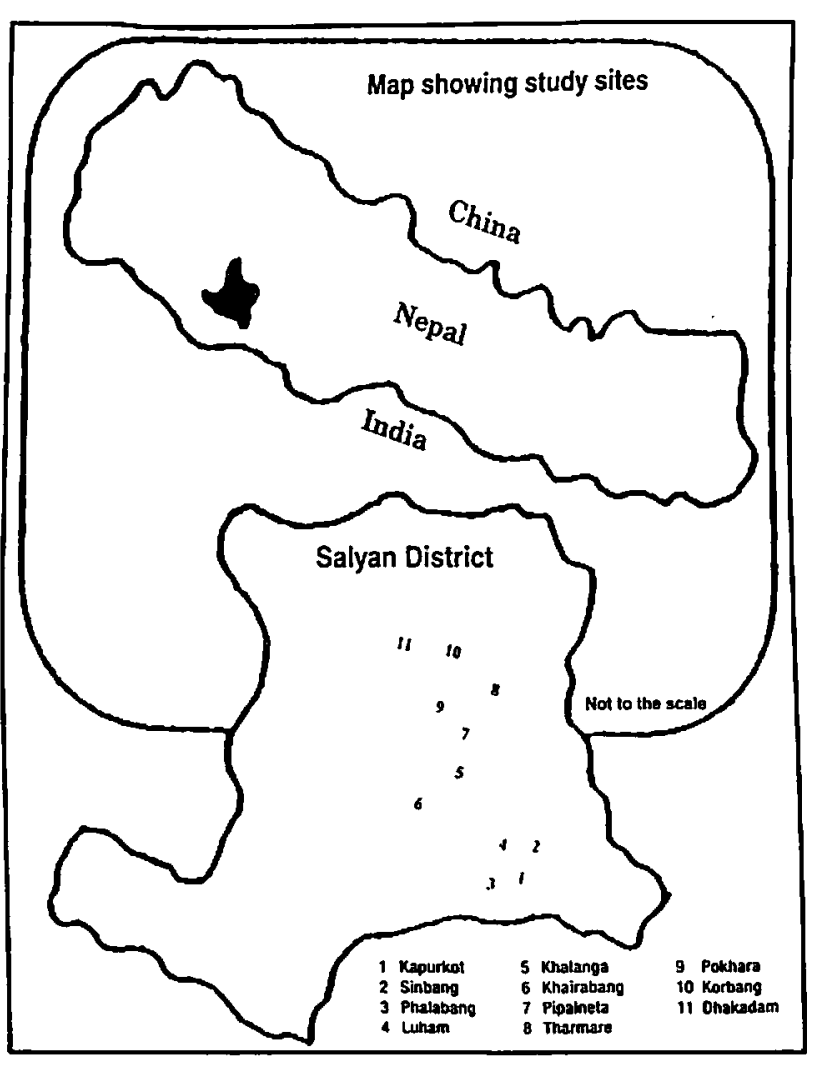

Godawari for detailed taxonomical identification. Upon preserving them in standard herbarium, they have been housed there for future use.

\section{Enumeration}

For the benefit of the readers, the identified plants have been arranged alphabetically in a tabular form with families in parenthesis, followed by Nepali names, and ethnomedical uses.

\section{Results and discussions}

Altogether 76 species of higher plants belonging to 54 families have been recorded here having different traditional medicinal properties. These species have been used to treat various ailments at the local-level. It includes the treatment of dislocated bones, migraine, cough and cold, diarrhoea, indigestion, anthelmintic, dyspepsia, skin diseases, ophthalmic troubles, antidotes, etc. Brief descriptions of ethnomedical uses of the plants have been presented in Table 1.

Table 1: Ethnomedical uses of Plants in Salyan district

\begin{tabular}{|c|c|c|c|}
\hline SN & Species & Local name & Ethnomedical uses \\
\hline 1 & $\begin{array}{l}\text { Pinus roxburgbii Sargent } \\
\text { (Pinaceae) }\end{array}$ & Sallo & $\begin{array}{l}\text { Root of Rumes nepalensis, root of Rberm australe, stem of Coelogyne } \\
\text { sp. and fresh needles of Pinus roxburgbii are crushed and boiled in } \\
\text { water and the solution is applied to set dislocated bone and to } \\
\text { reduce body pain. }\end{array}$ \\
\hline 2 & $\begin{array}{l}\text { Clematis bucbananiana } \\
\text { (Ranunculaceae) }\end{array}$ & Bagha junge & $\begin{array}{l}\text { The leaf juice is externally applied to skin diseases. Fine powder } \\
\text { from the fresh leaves is snuffed for treating migraine. }\end{array}$ \\
\hline 3 & $\begin{array}{l}\text { Cissanpelos pareira L. } \\
\text { (Menispermaceae) }\end{array}$ & Batulpate & The root past is given in case of colic, dyspepsia and diarrhoen. \\
\hline 4 & $\begin{array}{l}\text { Tiliacora acuminata } \\
\text { (Menispermaceae) }\end{array}$ & Gane gurjo & $\begin{array}{l}\text { The power of the underground part of the plant is given with } \\
\text { grain to the cattle as a tonic and in diarrhoea. }\end{array}$ \\
\hline 5 & $\begin{array}{l}\text { Berberis aristata DC } \\
\text { (Berberidaceae) }\end{array}$ & Chutro & A concentrated decoction of bark is used in conjunctivitis. \\
\hline 6 & $\begin{array}{l}\text { Berheris asiatica Roxb. ex DC. } \\
\text { (Berberidaceae) }\end{array}$ & Chutro & Same as Berberis aristata. \\
\hline 7 & $\begin{array}{l}\text { Argemone mexicana } \mathrm{L} \text {. } \\
\text { (Papaveraceae) }\end{array}$ & Pahel phoole & $\begin{array}{l}\text { The yellow latex of the plant is applied to cure conjunctivitis and } \\
\text { white spot in eye. }\end{array}$ \\
\hline 8 & $\begin{array}{l}\text { Rorippa nasturitium-aquaticum (L.) } \\
\text { Hayek (Cruciferae) }\end{array}$ & Simsag & $\begin{array}{l}\text { The young leaves and shoots are taken as green vegetable to treat } \\
\text { dysentery; also believed to be useful in goiter. }\end{array}$ \\
\hline 9 & $\begin{array}{l}\text { Drymaria diandra } \mathrm{Bl} \\
\text { (Caryophyllaceae) }\end{array}$ & Avijalo & $\begin{array}{l}\text { The juice of leaves is taken in indigestion, and the leaves are } \\
\text { smoldered over fire and inhaled through nose in case of headache. }\end{array}$ \\
\hline 10 & $\begin{array}{l}\text { Scbima nallichii (DC.) Korth. } \\
\text { (Theaceae) }\end{array}$ & Chilaune & $\begin{array}{l}\text { The fruit past is applied as an antidote for scorpion sting. The } \\
\text { stem bark is given with grain to the cattle against liver flukes and } \\
\text { intestinal worms. The wood is used for making ploughs. }\end{array}$ \\
\hline 11 & $\begin{array}{l}\text { Sborea robusta Gaertn. } \\
\text { (Dipterocarpaceae) }\end{array}$ & Sal & The powdered resin is taken with curd in dysentery. \\
\hline 12 & $\begin{array}{l}\text { Sida rhombifolia } \mathrm{I}_{*} \\
\text { (Malvaceae) }\end{array}$ & Balijhar & $\begin{array}{l}\text { Paste of leaves is applied on the ulcer to draw out pus from } \\
\text { wound. }\end{array}$ \\
\hline 13 & $\begin{array}{l}\text { Oxalis comiculata } \mathrm{L} \text {. } \\
\text { (Oxalidaceac) }\end{array}$ & Chriaamilo & $\begin{array}{l}\text { The juice of the plant is applied in conjunctivitis and white spot in } \\
\text { eyes. }\end{array}$ \\
\hline
\end{tabular}


14 Zantboxylum ammatum DC. Timur (Rutaceae)

15 Garuga pinnata Roxb. (Burseraceae)

16 Melia azedarach L. (Meliaceae)

17 Vitis lanata Roxb. (Vitaceac)

18 Mangifera indica $\mathrm{L}$. (Anacardiaceae)

19 Semecarpus anacardium L.f.

20 Coriaria nepalensis Wall. (Coriariaceae)

21 Baulinia vablii Wight et Arn. (Lcguminosae)

22 Butea buteiformis (Voigt) Grierson (Leguminosae)

23 Prunus persica (L.) Batsch. (Rosaceae)

24 Pyrus pascbia Buch.- Ham. ex D.Don (Rosaceae)

25 Rhus javanica $\mathrm{L}$. (Anacardaceae)

26 Rubus ellipticus $\mathrm{Sm}$. (Rubiaceae)

27 Bergenia ciliata (Haw.) Sternb. (Saxifragaceae)

28 Psidium guajava $\mathrm{L}$ (Myrtaceae)

29 Sysygism cumini (L.) Skcels (Myrtaceae)

30 Osbeckia stellata Buch.- Ham. cx D. Don (Melastomaceae)

31 Woodfordia fruticosa (L.) Kurz (Lythraceae)

32 Punica granatum L. (Punicaceae)

33 Carica papaya L. (Caricaceae)

34 Centella asiatica (L) Urban (Umbelliferae)

35 Ageratum conyzoides L. (Compositae)

36 Artenisia indica Willd. (Compositac)

37 Centipeda minima (L.) A. Br. \& Aschers. (Compositac)

38 Lyonia ovalifolia (Wall.) Drude (Ericaceae)

39 Rhododendion arboreum $\mathrm{Sm}$. (Ericaceae)

Purena

Amre

Malu

Aaru

Mayal

Ainselu

Silpho

Belauti

Jamun

Mewa

Pati

Angeri
Decoction of fruit with salt and powdered turmeric is taken to treat cough and cold.

Dabdabe The bark paste is applied on fresh wounds to stop bleeding and to heal wounds quickly. The bark of Ganga pinnata, root of Rumex nepalensis, fresh needle of Pinus roxburghii and red soil are boiled in water and the liquid used for setting bones and reducing body pain.

Bakaino The leaves juice is used as antiscorbutic.

The watery juice of the stem is used to cure white spot in the eye.

A paste of dried unripe fruit is given to cattle as an antidote.

Bhalayo

Machaeno

The oily seed is rubbed to cure chilblains.

The ripe fruits if eaten in large dose cause vomiting and intoxication.

The bark juice is given in dysentery.

Bhoojetro

Bhakiamilo

Kurkure

Dhayaro

Power of one seed is given once a day for a day as an anthelmintic.

A pest of the tender leaves is applied in wounds with maggots.

The ripe fruits are eaten raw to treat diarrhoea. The filtered juice of unipe fruit is used in cattle eye to cure white spot.

The powder fruits are taken with curd in diarrhoea and dysentery. The powder is applied on wounds between toes caused due to prolonged walking in mud.

The ripe fruits are eaten raw and the past is applied to treat wounds.

The thizome is used to treat urinary troubles and dysentery.

The warm leaves decoction of Psidium guajava with Pogostemon bengalensis is taken in catarrh. A past of seven tender tips is given in dysentery.

The bark juice is given in diarrhoea and dysentery.

The finely crushed root is taken with water in diarrhoea and colic.

Anaar

Ghortapre

Ramanña

Chhyunke

The dried flowers are given with curd in diarrhoea and dysentery:

A paste of rind with water is given in diarrhoea and dysentery.

The ripe fruits are eaten and the latex of the plant is used on the ringworm, and also applied in aching tooth and gums.

The juice of leaves is taken in fever and also improving memory. It is also taken as refrigerant with sugat-candy.

The juice of the leaves is applied to stop bleeding on cuts wounds.

The juice of the leaves is applied to stop bleeding on cuts and wounds.

A powder of the flowers is snuffed in cold and headache.

Laliguras
The young leaves and buds are poisonous to livestock. Also they are used as antiscorbutic.

The young leaves are poisonous to livestock. The wood is collected for fuel. 
40 Aesandra butyracea (Roxb.) Bachni Chiuri (Sapotaceae)

41 Calotropis gigantean (L.) Dryand. Aak (Asclepiadaceae)

42 Cuscuta reflexa Roxb. (Cuscutaccae)

43 Solanum aculeatissimum Jaq. (Solanaceae)

44 Solanum americanum Mill. (Solanaceae)

45 Solanum tuberosum L. (Solanaceae)

46 Justicia adbatoda L (Acanthaceae)

47 Callicarpa macropbylla Vahl (Vervenaceae)

48 Vitex negundo L. (Vervenaceae)

49 Colebrookea oppositifolia Sm. (Labiatae)

50 Mentba spicata L. (Labiatae)

51 Scutellaria discolor (Labiatae)

52 Mirabilis jalapa L. (Nyctaginaceae)

53 Acbyrantbes aspera $\mathrm{L}$. (Amranthaceae)

54 Amarantbus spinosus L. (Amranthaceae)

55 Chenopodium album $\mathrm{L}$. (Chenopodiaceae)

50 Rumex nepalensis Spreng. (Polygonaceae)

57 Osyris wightiana Wall. ex Wight (Santalaceae)

58 Chamaesyce birta (L.) Millsp. (Euphorbiaceae)

59 Eupborbia royleana Boiss. (Euphorbiaceae)

60 Jatropba curcas L. (Euphorbiaceae)

61 Sapium insigne (Royel) Benth. ex Hook. f.

(Euphorbiaceae)

62 Urtica dioica $\mathrm{L}$. (Urticaceae)

63 Cannabis sativa $L$. (Cannabinaceae)

64 Ficus semicorodata Buch.-Ham. Khanayo ex Sm. (Moraceae)

65 Engelhardia spicata Leschen. ex Mauwa Blume (Juglandaceae)

66 Juglans regia L. (Juglandaceae)

Koci

Aalu

Aasuro

Bhatesiti

Sevali

Basmati

Malti

Dation

Bethe

Halhale

Nune,

Shihudi

Sahijan

Khirro

Sisnoo

Bhang

Okhar
An edible butter obtained from seeds is externally applied in case of rheumatism and chilblains.

The milky latex of the plant is externally applied in case of rheumatism.

Aakash beli The juice of the plant is given with crushed garlic 0 the cattle in case of indigestion. Powder of the roosted stem is used externally to cure scabies.

Kantkari, The ripe fruits are smoldered over fire and smoke is inhaled through Beehi mouth to treat maggoty teeth.

Dhurseto

The past of the leaves is applied to relieve headache.

The past of tuber is applied externally on burn.

A decoction of leaves is taken in fever, asthma, cough and cold. The twigs are also used as toothbrush.

The plant bark is chewed to treat rashes on tongue.

Paadena,

Neelpate

Jamjeete,

Kademate

Nundhiki

Doodhajhar

The twigs are kept between the tooth to relieve toothache.

The plant part is kept between the teeth to treat toothache.

The juice of the leaves and onion is taken in vomiting.

The filtered leaf juice is taken in fever and catarrh.

The root is taken as purgative. A hot poultice of leaves is applied on sores.

The roots are tied around the waist of the pregnant women during labor pain to ease delivery.

The watery solution of the root is taken in burning sensation during urination. The leaf past is applied on the ulcer.

The tender parts of the plant and seeds are used to treat abdominal disorders.

Root of Rumex nepalensis, stem of Coelogyne sp., fresh needles of Pinus roxbueghii and the thizome of Rhesm australe all are crushed and boiled in water, the solution is applied to set dislocated bone and in injured parts to reduce pain.

The leaves are used as tea in case of urinaty disorder and to relieve body pain.

The milky latex is applied to stop bleeding from cuts. And also applied in eye to cure white spot.

The roasted pith is taken in case of stomach trouble and the milky latex is used as fish poison.

The twigs are used as toothbrush to cure discharge of blood from the gums.

The milky latex of the plant is used as fish poison.

The young leaves are used as glactogagoue. The past of leaves is applied on the cuts, and dog bite.

The roosted seeds are taken in mild doses as a tension relicver.

The milky latex is applied to the children navel in case of constipation.

A juice of bark is used as fish poison.

The twigs are used as toothbrush to cure discharge of blood from the gums. 


\begin{tabular}{|c|c|c|c|}
\hline 67 & $\begin{array}{l}\text { Alnss nepalensis D. Don } \\
\text { (Betulaceae) }\end{array}$ & Utis & $\begin{array}{l}\text { The concentrated decoction of mature bark is applied on the } \\
\text { wounds. A powder of the bark is applied to cure scabies. }\end{array}$ \\
\hline 68 & $\begin{array}{l}\text { Zingiber officinale Rose. } \\
\text { (Zingiberaceae) }\end{array}$ & Aduwa & The rhizome is chewed in cold and catarrhal affection. \\
\hline 69 & $\begin{array}{l}\text { Aloe vera (L.) Burm. f. } \\
\text { (Liliaceae) }\end{array}$ & Gheckumari & $\begin{array}{l}\text { The pulp of the roosted leaf is applied to burn and ulcer. Ten gram } \\
\text { each of roosted pulp and root are given in constipation. }\end{array}$ \\
\hline 70 & $\begin{array}{l}\text { Asparagus racemosus Willd. } \\
\text { (Liliaceae) }\end{array}$ & Kurilo & The ruberous are used as glactagogue. \\
\hline 71 & $\begin{array}{l}\text { Aconis calamus } \mathrm{L} \text {. } \\
\text { (Araccac) }\end{array}$ & Bojho & $\begin{array}{l}\text { The thizomes are chewed to cure cough and cold. The crushed } \\
\text { rhizome is used to cure indigestion }\end{array}$ \\
\hline 72 & $\begin{array}{l}\text { Agave cantula Roxb. } \\
\text { (Amaryllidaceae) }\end{array}$ & Kenuki & The juice of the leaves is used as fish poison. \\
\hline 73 & $\begin{array}{l}\text { Allium cepa } \mathrm{L} \\
\text { (Amaryllidaceae) }\end{array}$ & Piyaz & The juice of onion bulb and Mentha spicata is given in vomiting. \\
\hline 74 & $\begin{array}{l}\text { Dendrocalamus bamiltonii Nees \& } \\
\text { Arn. ex Munro } \\
\text { (Gramineae) }\end{array}$ & Bans & $\begin{array}{l}\text { Intake of green leaves for some days causes miscarriage, and the } \\
\text { leaves are said to cause sharp reduction in lactation. }\end{array}$ \\
\hline 75 & $\begin{array}{l}\text { Inperata glindrical (L.) Beauv. } \\
\text { (Gramineae) }\end{array}$ & Siru & Fine past of under ground stem of the plant is given as anthelmintic. \\
\hline 76 & $\begin{array}{l}\text { Thysanolaena latifolia (Roxb. ex } \\
\text { Hornem.) Honda } \\
\text { (Gramineac) }\end{array}$ & Amriso & A filtered juice of the root is taken in stomach pain. \\
\hline
\end{tabular}

\section{References}

Chaudhary, DC, Dobriyal, MJR and Guasia MS 2004. Holistic herbal healing. MFP News. Centre of Minor Forest Products, XIV (3): 3-7, Dehradun, India.

Chaudhary, RP. 1998. Biodiversity in Nepal: Status and Conservation. S. Devi, Saharanpur, India and Tecpress Books, Bangkok, Thailand, pp 324

Joshi, KK and Joshi, SD. 2001. Genetic Heritage of Medicinal and Aromatic Plants of Nepal
Himalayas. Buddha Academic Publishers and Distributors Pvt. Ltd. Kathmandu, Nepal, pp 239

Manandhar, NP. 2002. Plants and People of Nepal. Timber Press, Oregan, USA, pp 500.

Rajbhandari KR. 2001. Ethnobotany of Nepal. Ethnobotanical Society of Nepal c/o Central Department of Botany, TU, Kirtipur, Kathmandu, Pp 189.

Ved Prakash 1998. Indian medicinal plants-current status - I. Ethnobot. 10: 112-121 